\title{
Pharmacokinetic Evaluation of Once-Daily Topical 4\% Minocycline Foam in Adult and Pediatric Subjects With Moderate-to-Severe Acne in Two Phase 1 Studies
}

Terry M. Jones, MD'; Herman Ellman, MD²; Tina deVries, $\mathrm{PhD}^{2}$

'J\&S Studies, Inc., College Station, Texas, USA; Foamix Pharmaceuticals, Inc., Bridgewater, New Jersey, USA

\section{Background}

Acne vulgaris (AV) is a common skin disease that affects adolescents and can persist

The mainstay of treatment for $A V$ is systemic tetracyclines, such as doxycycline and

FMX1014\% is a novel topical foam formulation of minocycline. It has been shown to be an effective and well-tolerated treatment for moderate-to-severe $A V$ in a Phase 2
clinical trial Two Phase 1 studies were conducted to characterize minocycline pharmacokinetics (PK) and safety follwing m14-03) and pediatric (Study FX2016-21) patients with moderate-to-severe AV

\section{Methods}

2 Phase 1, single-center, nonrandomized, open-label studies (Figure 1, Table 1) Adults (age 18 to 35 years) or pediatric subjects (age 9 years to 16 years, 11 months)

Adult Study First received a single 1-mg/kg oral dose of oral extended(FX2014-03) release minocycline $\mathrm{HCl}$ tablet (Solodyn $)$. Then, after 10 days, they received a once-daily topical application of $4 \mathrm{~g}$ FMX101 upper arms for 21 days
uner chest, upper back, shoulders, and $\begin{array}{ll}\begin{array}{l}\text { Pediatric Study } \\ \text { (FX2016-21) }\end{array} & \text { the face, once-daily topical application of } 4 \mathrm{~g} \text { FMX101 4\% to } \\ \text { theper chest, upper back, shoulders, and upper }\end{array}$ the face, neck,
arms for 7 days

Figure 1. Study Design

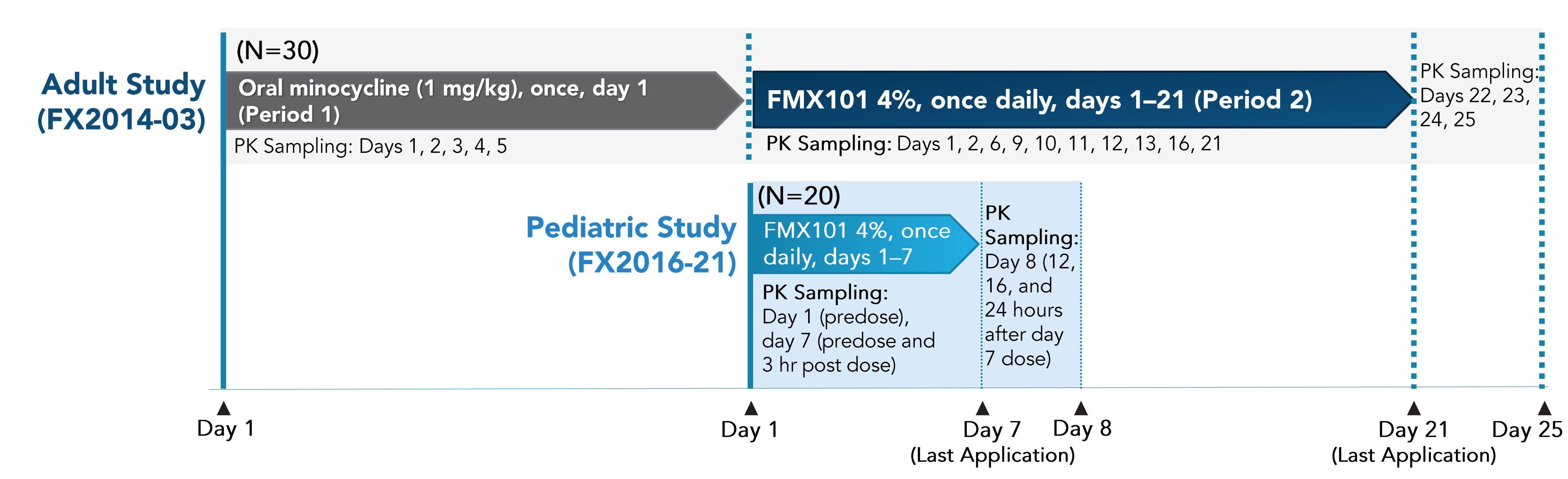

Table 1. Inclusion Criteria and Assessments

\begin{tabular}{|c|c|c|}
\hline & Adult Study (FX2014-03) & Pediatric Study (FX2016-21) \\
\hline Inclusion Criteria & $\begin{array}{l}\text { - Healthy males/females aged } \\
\text { 18-35 years } \\
\text { - Moderate-to-severe facial AV } \\
\text { (additionally affecting } \geq 2 \text { regions } \\
\text { of neck, upper chest, upper back, } \\
\text { or arms) } \\
\text { - BMI within } 18.5-29.9 \mathrm{~kg} / \mathrm{m}^{2} ; \text { body } \\
\text { weight within } 48.0-128.0 \mathrm{~kg} \\
\text { - Not pregnant, lactating, or } \\
\text { planning a pregnancy during study }\end{array}$ & $\begin{array}{l}\text { - Healthy males/females aged } \\
9 \text { years to } 16 \text { years, } 11 \text { months } \\
\text { - Subjects < } 12 \text { years: Mild facial } \\
\text { acne and acne of limited extent } \\
\text { - Subjects } 12-16 \text { years: } \\
\text { Moderate-to-severe AV based } \\
\text { on } 5 \text {-point IGA scale and acne } \\
\text { affecting } \geq 1 \text { of the following: } \\
\text { neck, upper chest, upper back, } \\
\text { or arms } \\
\text { - Sexually inactive, sterile, or using } \\
\text { contraception }\end{array}$ \\
\hline $\begin{array}{l}\text { Blood Sampling } \\
\text { for Drug } \\
\text { Concentration }\end{array}$ & $\begin{array}{l}\text { - Predose through } 96 \text { hours after } \\
\text { administration of oral minocycline } \\
\text { - Predose through } 24 \text { hours after } \\
\text { FMX101 4\% application on days } 1 \text {, } \\
12 \text {, and } 21 \\
\text { - Prior to scheduled application on } \\
\text { days } 6,9,10,11 \text {, and } 16 \\
\text { - On and after Day } 21, \text { at } 24 \text { hours } \\
\text { (Day 22), } 48 \text { hours (Day 23), } 72 \\
\text { hours (Day 24), and } 96 \text { hours } \\
\text { (Day 25) from last application of } \\
\text { FMX101 4\% }\end{array}$ & $\begin{array}{l}\text { - On day } 7 \text {, after } 3,12,16 \text {, and } \\
24 \text { hours from last application of } \\
\text { FMX101 4\% }\end{array}$ \\
\hline $\begin{array}{l}\text { Pharmacokinetic } \\
\text { Analyses }\end{array}$ & 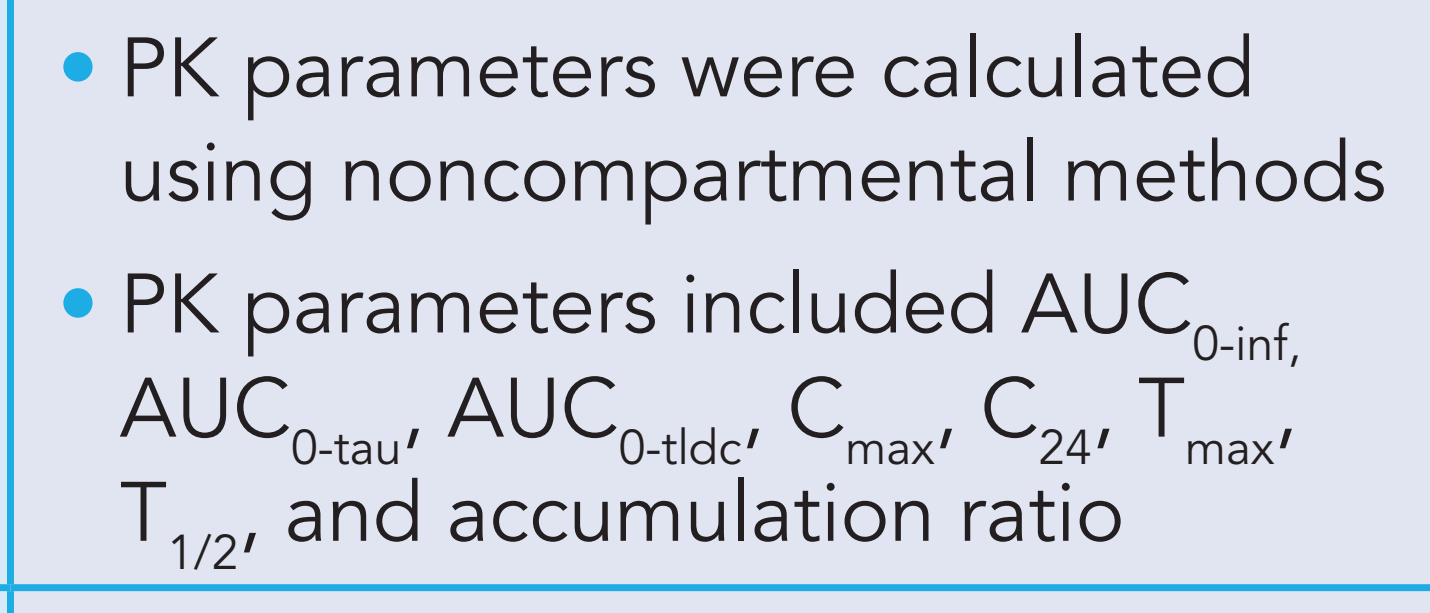 & $\begin{array}{l}\text { - PK parameters were calculated } \\
\text { using noncompartmental methods } \\
\text { - PK parameters included } A U C_{0 \text {-tau' }} \\
\mathrm{C}_{\text {max }} \text { and } \mathrm{C}_{24}\end{array}$ \\
\hline $\begin{array}{l}\text { Statistical } \\
\text { Analyses }\end{array}$ & $\begin{array}{l}\text { - Geometric mean was calculated } \\
\text { for } A \cup C_{0 \text {-int' }} A \cup C_{0 \text {-tau' }} A \cup C_{0 . t d c^{\prime}} \text { and } \\
C_{\max }\end{array}$ & $\begin{array}{l}\text { - Geometric mean was calculated } \\
\text { for } A \cup C_{0 \text {-tau }} \text { and } C_{\text {max }}\end{array}$ \\
\hline
\end{tabular}

$A U C_{0 \text { int }}=A U C$ from 0 to infinity

$A \cup C_{0: \text { tau }}=A U C$ during the 24-hour dosing interval.

$A \cup C_{0.1 d d}=A U C$ from 0 to time of last determinable concentration. $\mathrm{C}_{\text {max }}=$ maximum plasma drug concentration.

$T_{1 / 2}=$ terminal phase half-II

$T_{\text {max }}=$ time of maximum
BMI=body mass index.

IGA=Investigator's Global Assessment.

References

1. Picardo M, et al. Dermatol Ther (Heidelb). 2017;7:43-52. Zaenglein AL, et al. J Am Acad Dermatol. 2016;74:945-973.
Shemer A, et al. J Am Acad Dermatol. 2016;74:1251-1252.

\section{Results}

Baseline Demographics

Baseline characteristics are shown in Table 2

- All adult subjects had moderate-to-severe AV

- A majority of pediatric subjects (90\%) had moderate AV, and 1 subject had mild AV

Table 2. Baseline Characteristics

\begin{tabular}{|c|c|c|}
\hline & 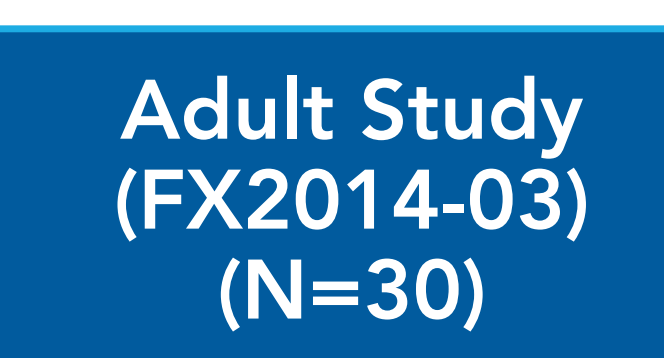 & $\begin{array}{l}\text { Pediatric Study } \\
(\mathrm{F}=2016-21) \\
(\mathrm{N}=20)\end{array}$ \\
\hline Mean age (range), yr & $22.6(18-30)$ & $13.2(10-16)$ \\
\hline $\begin{array}{c}\text { Gender, n (\%) } \\
\text { Male/Female }\end{array}$ & $12(40) / 18(60)$ & $9(45) / 11(55)$ \\
\hline $\begin{array}{l}\text { Race, } \mathrm{n}(\%) \\
\text { White } \\
\text { Black or African American }\end{array}$ & $\begin{array}{c}27(90) \\
3(10) \\
\end{array}$ & $\begin{array}{l}7(35) \\
13(65) \\
\end{array}$ \\
\hline $\begin{array}{l}\text { Ethnicity, } \boldsymbol{n}(\%) \\
\text { Hispanic/Latino } \\
\text { Non-Hispanic/Latino }\end{array}$ & $\begin{array}{l}11(36.7) \\
19(63.3)\end{array}$ & $\begin{array}{l}2(10) \\
18(90)\end{array}$ \\
\hline
\end{tabular}

\section{Pharmacokinetics - Adults}

- The mean plasma concentration of oral minocycline in adult subjects reached $C_{\text {max }}$ by
3 hours after administration, followed by a log-linear decrease in concentration for the 3 hours after administration, follow

The mean plasma minocycline concentration of FMX101 4\% increased until 8-14 hours (median $\mathrm{T}$ value) on days 1,12 , and 21

Figure 2 shows a comparison of mean plasma minocycline concentrations during the FMX101 $4 \%$ at 3 timepoints in adult subjects

In adult subjects, oral minocycline treatment had a geometric mean $\mathrm{C}_{\max }$ of $850 \mathrm{ng} / \mathrm{mL}$,

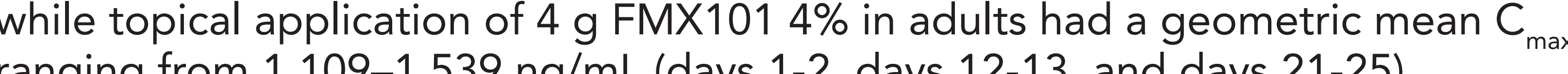

Steady state was achieved on day 6 of treatment

Figure 2. Mean Plasma Minocycline Concentration Over the First 24 Hours Following a Single Dose of Oral Minocycline and Topical Application of FMX101 4\% (Semi-log Scale) in Adult Subjects (Study FX2014-03)

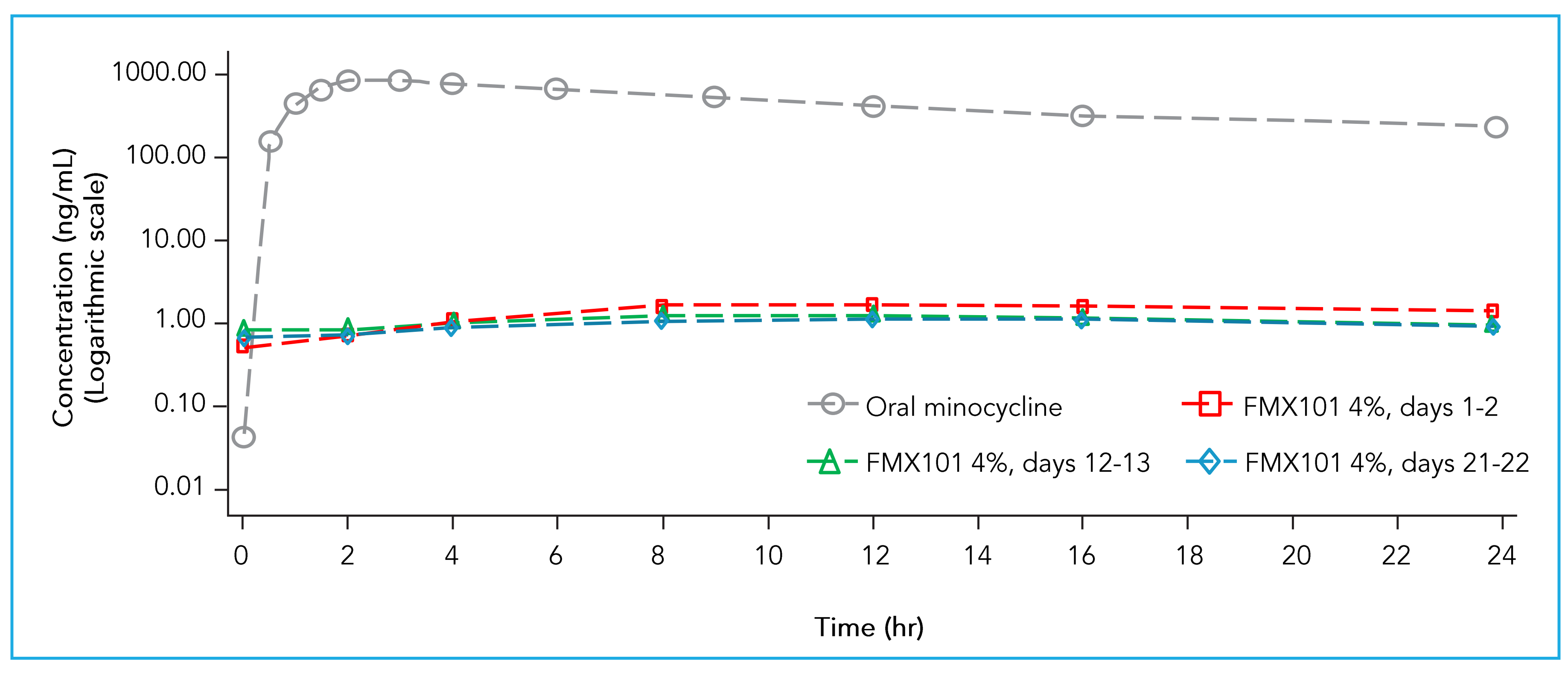

- In adults, minocycline exposure with daily topical application of FMX1014\% for 21 days was 730 to 765 times lower than that with oral minocycline (Table 3)

Table 3. Summary of Minocycline Relative Bioavailability With Oral Minocycline Administration (Reference) and To
and Day 21 (Study FX2014-03)

\begin{tabular}{|c|c|c|c|c|c|}
\hline \multirow[b]{2}{*}{$\begin{array}{l}\text { FMX101 4\% } \\
\text { vs } \\
\text { Oral Minocycline }\end{array}$} & \multirow[b]{2}{*}{$\mathbf{N}$} & \multicolumn{2}{|c|}{ Geometric Mean ${ }^{2}$} & \multirow[b]{2}{*}{$\begin{array}{c}\text { Geometric LSM } \\
\text { Test//Reference } \\
\text { Ratio, } \% \text { \% }(90 \% \mathrm{Cl})\end{array}$} & \multirow[b]{2}{*}{$1 / \mathrm{GM}$} \\
\hline & & $\begin{array}{c}\text { FMX101 4\% } \\
\text { (Test) }\end{array}$ & $\begin{array}{c}\text { Oral } \\
\text { Minocycline } \\
\text { (Ref) }\end{array}$ & & \\
\hline Day $12 C_{\max }$ & 29 & 1.06 & 846 & $0.126(0.100,0.159)$ & 794 \\
\hline Day $21 C_{\max }$ & 30 & 1.11 & 850 & $0.131(0.113,0.151)$ & 763 \\
\hline Day $12 \mathrm{AUC}^{\mathrm{c}}$ & 29 & 20.06 & 14976 & $0.134(0.110,0.163)$ & 746 \\
\hline Day $21 \mathrm{AUC}^{\mathrm{d}}$ & 30 & 20.07 & 15060 & $0.137(0.121,0.156)$ & 730 \\
\hline
\end{tabular}

\section{Conclusions}

In adult subjects, mean minocycline AUC and $C_{\text {max }}$ values were substantially lower following the daily topical application of $4 \mathrm{~g}$ FMX $1014 \%$ for 21 days in comparison

There was no evidence of accumulation in adult subjects receiving daily topical application of FMX101 $4 \%$ for up to 21 days
Pharmacokinetics - Pediatrics

In pediatric subjects, the overall plasma concentrations of minocycline following the oplication of FMX1014\% once daily for 7 days were relatively constant over day 7 $\sim 2.5 \mathrm{ng} / \mathrm{mL}$ ) (Figure 3)

Figure 3. Mean Plasma Concentrations of Minocycline Following Application of FMX101 4\% Once Daily for 7 Days in Pediatric Subjects (Study FX2016-21)

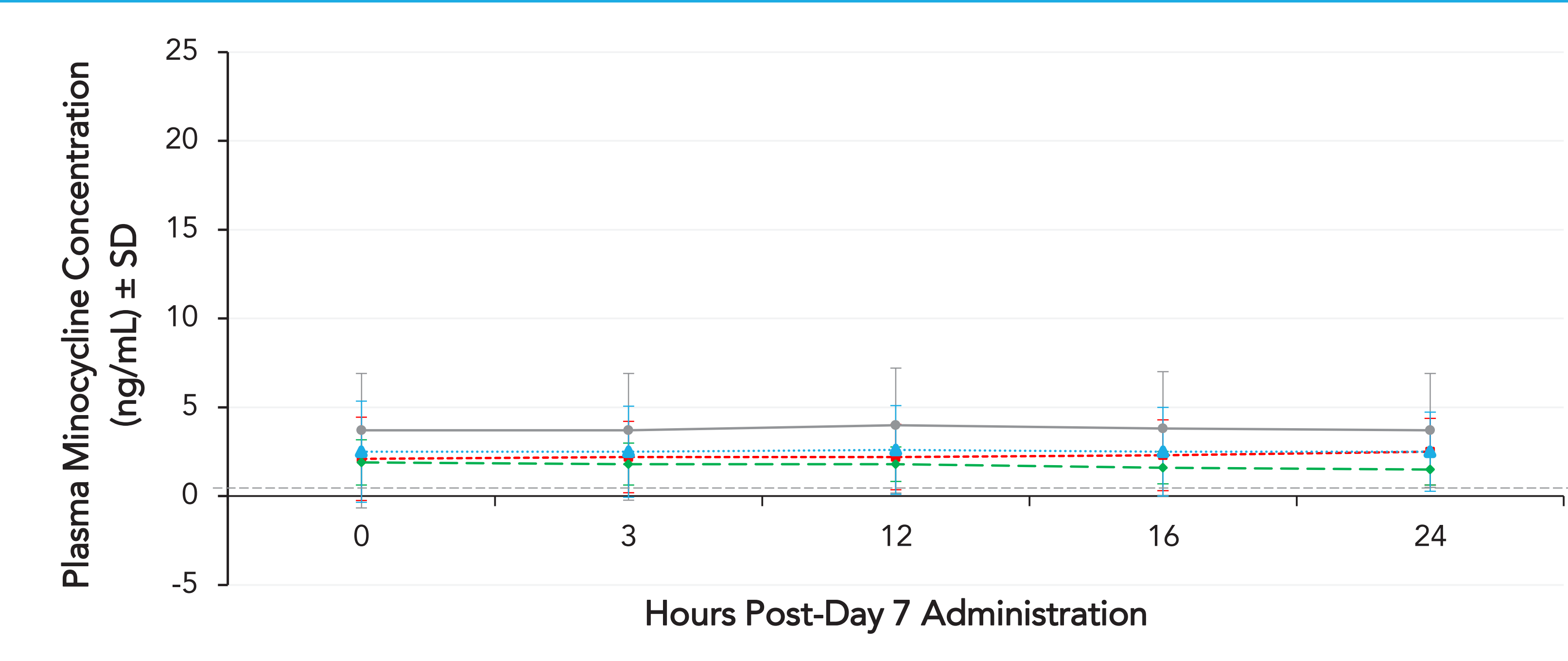

$\mathrm{OQ}=$ =lower limit of quantication: $\mathrm{SD}=$ standard deviation There were no substantial differences in mean concentrations of minocycline among

Across all cohorts, the geometric mean $\mathrm{C}_{\text {max }}$ value was $2.4 \mathrm{ng} / \mathrm{mL}$

Table 4. Pharmacokinetic Parameters of Minocycline in Plasma in Pediatric Acne Subjects Treated With FMX101 4\% (Study FX2016-21)

\begin{tabular}{|c|c|c|c|c|c|}
\hline \multirow[b]{2}{*}{ Age Group } & \multirow[b]{2}{*}{$\mathbf{N}$} & \multicolumn{3}{|c|}{ Geometric Mean } & \multirow[b]{2}{*}{$T_{\text {max }}(h r)^{a}$} \\
\hline & & $C_{\max }(n g / m L)$ & $\begin{array}{c}\mathrm{AUC} \\
\left(\mathrm{ng}^{*} \mathrm{k} / \mathrm{h} / \mathrm{mL}\right)\end{array}$ & $\mathrm{C}_{24}(\mathrm{ng} / \mathrm{mL})$ & \\
\hline 9-11 years & 6 & 3.522 & 68.175 & 2.933 & $12(0,24)$ \\
\hline $12-14$ years & 8 & 2.250 & 42.167 & 1.998 & $20(0,24)$ \\
\hline 15-16 years, 11 months & 6 & 1.735 & 35.067 & 1.302 & $6(0,24)$ \\
\hline Overall & 20 & 2.381 & 46.087 & 1.972 & $12.1(0,24)$ \\
\hline
\end{tabular}

Safety

In both adult and pediatric subjects, daily application of FMX1014\% was found to be safe and well tolerated (Table 5 )

No adult or pediatric subjects experienced a serious treatment-emergent advers study

9 adult subjects in the FMX101 4\% group reported 1 or more TEAES; all were mild or moderate in intensity (FX2014-03)

A single pediatric subject experienced 2 unrelated TEAEs (nausea and vomiting)

Table 5. Overall Summary of TEAEs Following Administration of Oral Minocycline and Topical Application of FMX101 4\% in Adult and Pediatric Subjects

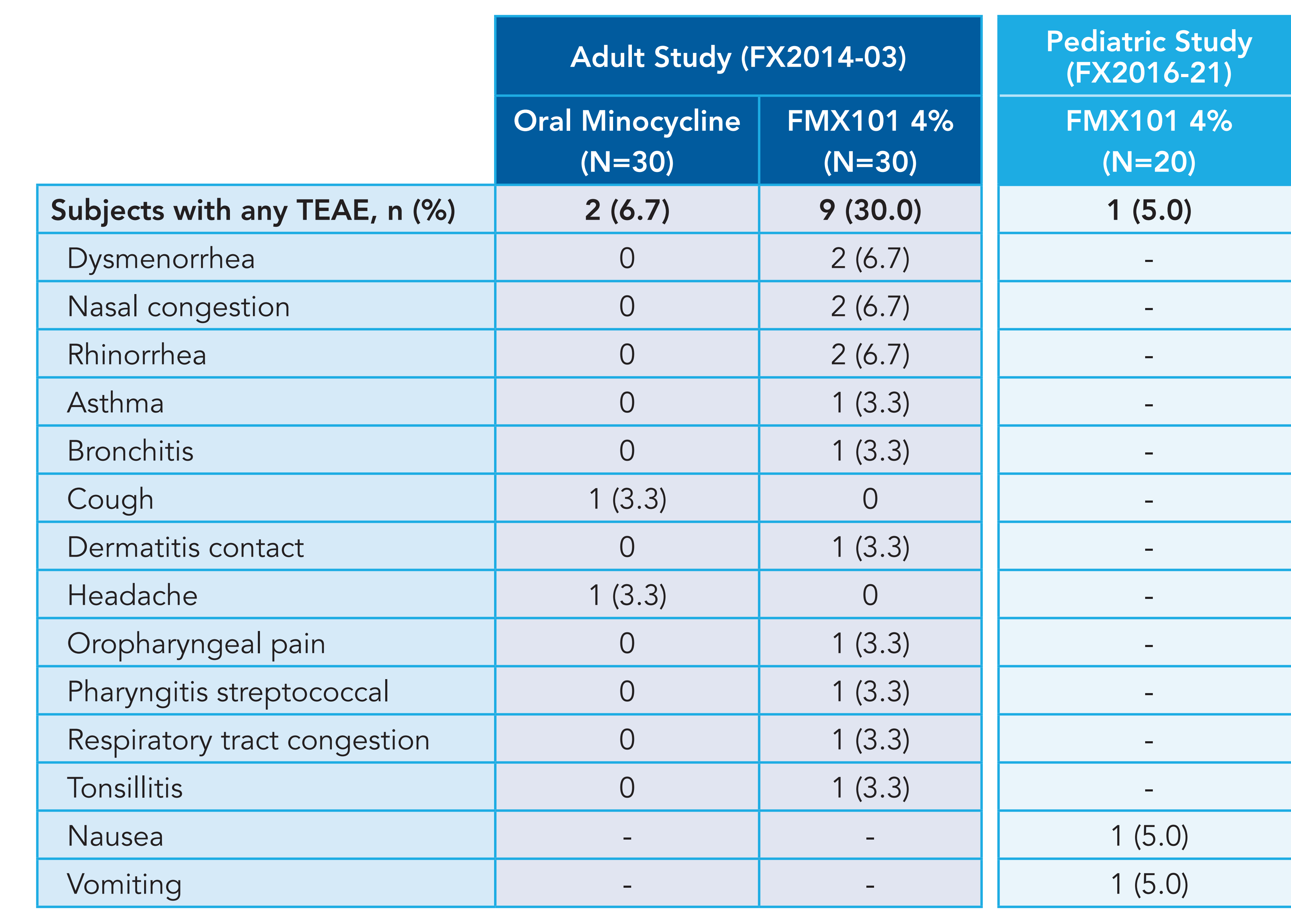

In pediatric subjects, mean minocycline $C_{\text {max }}$ and $A U C$ values following the daily topical application of $4 \mathrm{~g}$ FMX1014\% for 7 days were $2.4 \mathrm{ng} / \mathrm{mL}$ and $46.1 \mathrm{ng} \mathrm{hr}^{\star} / \mathrm{mL}$, $20.1 \mathrm{ng} * \mathrm{hr} / \mathrm{mL}$, respectively, indicating similar minimal systemic exposure Pediatric subjects in all 3 age cohorts had similar levels of minocycline $(\sim 2.5 \mathrm{ng} / \mathrm{mL}$ )
across the dosing interval with daily application of FMX1014\% for 7 days Once-daily topical application of FMX1014\% for 7 days and 21 days was shown to be safe and well tolerated in pediatric and adult subjects, respectively 